\title{
Penentuan Aktivitas Antioksidan dan Kandungan Flavonoid Total Ekstrak Daun Papasan (Coccinia grandis L.) Berdasarkan Perbedaan Pelarut Polar
}

\section{[Determination of Antioxidant Activity and Total Flavonoid Contents Extract of Papasan Leaves (Coccinia grandis L.) Based on The Differences Polar Solvents]}

\author{
Meliani Sari, Rani Nareza Ulfa, Mauritz Pandapotan Marpaung*, Purnama \\ Fakultas Farmasi, Universitas Kader Bangsa, Palembang
}

\begin{abstract}
Papasan leaves have several properties, including antihyperglycemic, diabetes, antipyretic and antioxidant. Minor metabolite compounds that have the potential as antioxidants from this plant are flavonoids, alkaloids, saponins, and tannins. This study's purpose to determine the antioxidant activity and the flavonoid total contents of Papasan (Coccinia grandis L.) leaf extract based on the differences in polar solvents. The polar solvents used were ethanol, methanol, and water. Extraction used by maceration and dekokta. The antioxidant activity and the flavonoid total contents were established by UV-Vis spectrophotometry according to the decrease in absorbance at a maximum wavelength of $515 \mathrm{~nm}$ by the DPPH (2,2-diphenyl-1-picrylhydrazyl) method. Determination of antioxidant activity and the flavonoid total contents were excluded on quercetin comparisons. The values of $\mathrm{IC}_{50}$ and the flavonoid total contents in the ethanol extract respectively were $287.92 \mathrm{ppm}$ and $49.825 \mathrm{mg}$ $\mathrm{QE} / \mathrm{g}$ while the $\mathrm{IC}_{50}$ values and total flavonoid levels in the extract of methanol were $73.29 \mathrm{ppm}$ and $50.415 \mathrm{mg}$ $\mathrm{QE} / \mathrm{g}$. In the extract of the water, the value of $\mathrm{IC}_{50}$ was $39.80 \mathrm{ppm}$ and the total flavonoid contents were $50.415 \mathrm{mg}$ $\mathrm{QE} / \mathrm{g}$. The conclusions of these studies were that the most antioxidant activity was found in water extract, while water and methanol extract had the same and highest levels of total flavonoids.
\end{abstract}

Keywords: Antioxidant, flavonoid, papasan leaves

Abstrak. Daun Papasan memiliki beberapa khasiat antara lain sebagai antihiperglikemia, diabetes, antipiretik dan antioksidan. Senyawa dari metabolit sekunder yang berpotensi sebagai antioksidan dari tanaman ini antara lain flavonoid, saponin, alkaloid dan tanin. Tujuan penelitian ini untuk menentukan aktivitas antioksidan dan kadar flavonoid total ekstrak daun Papasan (Coccinia grandis L.) berdasarkan perbedaan pelarut polar. Pelarut polar yang digunakan yaitu etanol, metanol dan air. Ekstraksi dilakukan dengan cara maserasi dan dekokta. Aktivitas antioksidan dan kandungan flavonoid total ditentukan secara spektrofotometri UV-Vis berdasarkan penurunan absorbansi pada panjang gelombang maksimum $515 \mathrm{~nm}$ dengan menggunakan metode 2,2-difenil-1-pikrilhidrazil (DPPH). Penentuan aktivitas antioksidan dan kandungan flavonoid total dilakukan terhadap pembanding kuersetin. Nilai $\mathrm{IC}_{50}$ dan kandungan flavonoid total pada ekstrak etanol masing-masing adalah 287,92 ppm dan 49,825 mg QE/g sedangkan nilai IC 50 dan kandungan flavonoid total pada ekstrak metanol berturut-turut adalah 73,29 ppm dan 50,415 mg QE/g. Pada ekstrak air, nilai $I_{50}$ sebesar 39,80 ppm dan kandungan flavonoid total adalah 50,415 $\mathrm{mg}$ QE/g. Kesimpulan penelitian ini adalah aktivitas antioksidan tertinggi terdapat pada ekstrak air sedangkan ekstrak metanol dan air memiliki kandungan flavonoid total yang sama dan tertinggi.

Kata kunci : Antioksidan, flavonoid, daun papasan

Diterima: 13 Januari 2021, Disetujui: 8 April 2021

Sitasi: Sari, M., Ulfa, R.N., Marpaung, M.P., \& Purnama. (2021). Penentuan Aktivitas Antioksidan dan Kandungan Flavonoid Total Ekstrak Daun Papasan (Coccinia grandis L.) Berdasarkan Perbedaan Pelarut Polar. KOVALEN: Jurnal Riset KImia, 7(1): 30-41.

\footnotetext{
* Corresponding author

E-mail: mauritzchem@gmail.com (hp: 081272231665)
} 


\section{LATAR BELAKANG}

Radikal bebas adalah produk normal dari proses metabolisme tubuh atau dapat pula terbentuk di luar tubuh. Senyawa yang mempunyai berat molekul kecil tetapi mampu menghambat kerusakan sel akibat radikal bebas dengan cara memberikan elektron disebut antioksidan (Purwandari et al., 2018). Sumber-sumber antioksidan berupa antioksidan sintetik maupun antioksidan alami. Penggunaan antioksidan sintetik mulai dibatasi karena antioksidan sintetik seperti BHT (Butylated Hydroxy Toluena) terbukti bersifat karsinogenik dan dapat meracuni hewan percobaan. Maka dari itu, industri makanan dan obat-obatan menggunakan antioksidan alami (Wahyuningsih, 2013).

Senyawa antioksidan alami tumbuhan yaitu senyawa fenolik atau polifenolik yaitu berupa golongan flavonoid, turunan asam sinamat, tokoferol, asam-asam organik polifungsional, dan kumarin. Flavonoid memiliki kemampuan sebagai antiradikal bebas dan pereduksi radikal bebas (Pietta, 2000).

Flavonoid ditemukan dalam tumbuhtumbuhan di alam adalah senyawa fenol yang terbesar yang merupakan zat warna merah, biru, dan ungu, dan sebagian zat warna kuning yang (Arukwe et al., 2012). Flavonoid berfungsi sebagai penurun kandungan gula darah, sebagai stimulan pada jantung, diuretik, antijamur, antibakteri, antiinflamasi, antitumor, antialergi, pencegah osteoporosis, dan pencegah penyakit kardiovaskuler dengan menurunkan laju oksidasi lemak serta dapat menurunkan kolesterol yang tinggi pada manusia (Nurjanah et al., 2011).

Untuk memperoleh senyawa aktif berupa flavonoid dan aktivitasnya sebagai antioksidan dari bahan alam diperlukan jenis pelarut yang sesuai dalam ekstraksi. Hal ini sesuai dengan prinsip like dissolves like yaitu pengambilan senyawa aktif dalam tumbuhan dilakukan melalui ekstraksi pelarut yaitu suatu pelarut akan cenderung melarutkan senyawa yang memiliki tingkat kepolaran yang sama. Pelarut polar akan melarutkan senyawa polar dan sebaliknya (Arifianti et al., 2014). Pelarut polar yang biasanya dapat digunakan dalam ekstraksi berupa etanol, metanol, dan air.

Salah satu tanaman yang berpotensi memiliki aktivitas antioksidan adalah tanaman Papasan (Coccinia grandis L). Pada bagian tanaman ini seperti akar, dan buah mempunyai berbagai khasiat seperti antihiperglikemia, antidiabetes, analgesik, antipiretik, mengobati penyakiit kulit, dan infeksi saluran kemih. Sedangkan bagian daun memiliki sifat sebagai antioksidan, antidabetes, dan juga digunakan untuk mengobati penyakit gonore, hipolipidemik, penyakit kulit, infeksi pada saluran kemih, infeksi malaria dan kencing nanah (Pekamwar et al., 2013). Selain itu, daun ini juga memiliki khasiat sebagai antimikroba, antihiperlipidemia, antitusif dan antiulcer (Aggarwal et al., 2011).

Pada hasil penelitian sebelumnya, kombinasi ekstrak daun papasan dengan buah belimbing wuluh dalam pelarut air memiliki kandungan flavonoid total sebesar 134,91 \pm 2,63 mg QE/g (Ate et al., 2019). Pada kombinasi ekstrak daun papasan dengan daun sembung dalam pelarut air memiliki aktivitas antioksidan ( $\left.\mathrm{IC}_{50}\right)$ sebesar $5,21 \pm 1,75 \mathrm{mg} / \mathrm{mL}$ (Atikawati et al., 2019). Pada buah Papasan mengandung kadar flavonoid dan aktivitas antioksidan dalam pelarut metanol masingmasing sebesar 82,8 \pm 7,8 mg QE/g dan 6,12 $\mu \mathrm{g} / \mathrm{mL}$ (Kondhare \& Lade, 2017). Sementara itu, penetapan kadar flavonoid dan aktivitas 
antioksidan ekstrak daun papasan tanpa kombinasi dalam pelarut metanol, air dan etanol belum diuraikan secara utuh sebelumnya.

Penggunaan pelarut polar seperti etanol, metanol dan air dalam penelitian ini bertujuan untuk memperoleh kandungan flavonoid dan aktivitas antioksidan tertinggi dari ekstrak daun papasan sehingga mendapatkan pelarut yang tepat untuk menyari senyawa-senyawa aktif tersebut secara optimal.

\section{METODE PENELITIAN}

\section{Bahan dan Peralatan}

Bahan-bahan yang digunakan berupa daun Coccinia grandis L., akuades (Dira Sonita), metanol p.a (Merck), etanol p.a (Merck), 2,2-diphenyl-1-picrylhydrazyl (DPPH) (Sigma-aldrich), kuersetin (Sigma-aldrich), Aluminium (III) klorida $2 \%$, asam asetat, $\mathrm{HCl}$, $\mathrm{NaOH} 10 \%$, dan serbuk magnesium.

Alat yang digunakan antara lain botol maserasi, pisau, neraca analitik ( $A \& D$ company limited), spatula, kertas saring no 1 (Whatmann), ayakan mesh 60, kuvet (Spectra Cuvette), tabung reaksi (Pyrex), vial, corong (Herma), pipet volume (Iwaki), gelas ukur (Herma), gelas kimia (Pyrex), rotary evaporator $(S H Z-D)$, labu ukur (Herma), plat tetes, penangas air (Memmert), dan spektrofometer UV-Vis (Shimadzu UVmini-1240).

\section{Prosedur Penelitian}

\section{Determinasi sampel}

Determinasi tumbuhan Papasan diperoleh dari daerah Prabumulih, Sumatera Selatan dilakukan di Laboratorium Biologi, STI Pertanian Sriwigama, Palembang.

\section{Pembuatan simplisia daun Papasan}

Daun Papasan segar yang telah dipetik, dicuci bersih, dirajang dan disortasi basah.
Kemudian disortasi kering dan dihaluskan. Selanjutnya untuk memperoleh simplisia diayak dengan mesh 60 dan ditimbang bobot simplisia yang dihasilkan.

\section{Pembuatan ekstrak etanol dan metanol daun Papasan}

$200 \mathrm{~g}$ simplisia dilarutkan masingmasing pelarut metanol dan etanol ke dalam botol maserasi sampai seluruh sampel terendam dalam kurun waktu 3 hari. Sampel disimpan di tempat terlindung dari cahaya matahari langsung sambil dikocok sesekali. Lalu diremaserasi sebanyak 2 kali selam 3 hari. Filtrat diperoleh lalu diuapkan dengan alat rotary evaporator pada suhu $50^{\circ} \mathrm{C}$ dan dipekatkan di atas waterbath. Setelah itu dilakukan penimbangan ekstrak kental dan dihitung persentase rendemen yang dihasilkan.

\section{Pembuatan ekstrak air daun Papasan}

$200 \mathrm{~g}$ simplisia diekstraksi melalui metode dekokta dengan menambahkan air hingga 2000 mL. Selanjutnya dipanaskan dalam waterbath selama 30 menit yang terhitung setelah suhu dalam gelas kimia telah mencapai $90^{\circ} \mathrm{C}$ (Rizkayanti et al., 2017).

\section{Uji fitokimia ekstrak daun Papasan}

1. Uji alkaloid

Ekstrak ditambahkan dengan $5 \mathrm{~mL}$ asam klorida $2 \mathrm{~N}$ ke dalam 2 tabung reaksi (Simaremare, 2014). Tabung reaksi yang pertama ditambahkan 3 tetes pereaksi Mayer memberikan endapan putih hingga kekuningan. Tabung reaksi yang kedua ditambahkan 2 tetes pereaksi Dragendorff memberikan endapan jingga. Jika terjadi endapan atau kekeruhan pada dua percobaan tersebut maka terdapat alkaloid pada ekstrak

2. Uji flavonoid

$$
\text { Ketiga fraksi masing-masing }
$$


dimasukkan ke dalam 3 tabung reaksi sebanyak $1 \mathrm{~mL}$. Tabung reaksi yang pertama direaksikan dengan 2-4 tetes asam klorida pekat dan serbuk magnesium. Adanya flavonoid pada ekstrak ditandai dengan warna merah. Pada tabung yang kedua ditambahkan asam klorida pekat beberapa tetes, dipanaskan selama 15 menit di atas waterbath. Terbentuknya warna jingga menunjukkan terdapat flavonoid. Pada tabung yang ketiga ditambahkan larutan $\mathrm{NaOH} 10 \%$ beberapa tetes. Warna kemerahan menunjukkan terdapat flavonoid pada ekstrak (Zirconia et al., 2015).

3. Uji tanin

$1 \mathrm{~g}$ ekstrak ditambahkan dengan $10 \mathrm{~mL}$ air panas. Kemudian ditetesi besi (III) klorida. Adanya warna hijau kehitaman menunjukkan ekstrak mengandung tanin (Farah et al., 2019).

4. Uji saponin

$1 \mathrm{~g}$ ekstrak ditambahkan dengan $10 \mathrm{~mL}$ akuades. Lalu dikocok kuat selama kurang lebih 1 menit dan didiamkan selama 10 menit. Terdapat buih stabil selama 10 menit dengan tinggi $3 \mathrm{~cm}$ menunjukkan ekstrak mengandung saponin (Farah et al., 2019).

5. Uji steroid/triterpenoid

$1 \mathrm{~g}$ sampel ditambahkan dengan $2 \mathrm{~mL}$ kloroform lalu dikocok. Filtrat ditambahkan asetat anhidrat dan asam sulfat pekat masing-masing sebanyak 2 tetes. Adanya steroid menunjukkan warna biru atau hijau. Sedangkan adanya triterpenoid menunjukkan warna merah atau ungu (Farah et al., 2019).

\section{Pembuatan larutan DPPH 40 ppm}

$4 \mathrm{mg}$ kristal DPPH dilarutkan dengan metanol hingga $100 \mathrm{~mL}$ ke dalam labu ukur (Farah et al., 2019).

\section{Penentuan panjang gelombang maksimum DPPH}

$2 \mathrm{~mL}$ larutan DPPH $40 \mathrm{ppm}$ dalam tabung reaksi ditambahkan sebanyak $2 \mathrm{~mL}$ metanol, dikocok hingga homogen. Lalu dimasukkan ke dalam kuvet sebanyak $3 \mathrm{~mL}$ dan diukur pada panjang gelombang maksimum $515 \mathrm{~nm}$ (Farah et al., 2019).

\section{Pembuatan larutan standar kuersetin}

10 mg kuersetin dilarutkan dengan metanol sampai $100 \mathrm{~mL}$ ke dalam labu ukur sehingga diperoleh konsentrasi larutan standar kuersetin 100 ppm. Lalu dibuat variasi konsentrasi yaitu 20; 40; 60; 80; dan 100 ppm dengan masing-masing larutan standar dipipet 5; 10; 15; 20; dan 25 mL. Lalu ditambahkan dengan metanol hingga $25 \mathrm{~mL}$ (Farah et al., 2019).

\section{Pembuatan larutan ekstrak daun Papasan}

$10 \mathrm{mg}$ ekstrak etanol daun Papasan dilarutkan dengan metanol hingga $100 \mathrm{~mL}$ dalam labu ukur sehingga diperoleh konsentrasi ekstrak etanol daun Papasan 100 ppm. Lalu dibuat variasi konsentrasi yaitu 20; 40; 60; 80; dan 100 ppm dengan masingmasing larutan standar dipipet $5 ; 10 ; 15 ; 20$; dan $25 \mathrm{~mL}$. Lalu tambahkan dengan metanol hingga $25 \mathrm{~mL}$ (Farah et al., 2019).

\section{Uji antioksidan larutan standar kuersetin}

$2 \mathrm{~mL}$ larutan standar kuersetin dimasukkan ke dalam tabung reaksi. Lalu ditambahkan DPPH 40 ppm sebanyak $2 \mathrm{~mL}$, diinkubasi dalam ruang gelap selama 30 menit. Pengukuran absorbansi diukur dengan spektrofotometer UV-Vis dan dibuat kurva baku larutan standar kuersetin (Farah et al., 2019).

\section{Uji antioksidan ekstrak daun Papasan}

1. Uji kualitatif antioksidan ekstrak Daun Papasan

Sebanyak $10 \mathrm{mg}$ masing-masing ekstrak ditambahkan DPPH 40 ppm 
sebanyak 5 tetes dan diamati perubahan warna larutan. Adanya perubahan warna larutan dari warna ungu menjadi warna kuning menunjukkan adanya aktivitas antioksidan (Farah et al., 2019).

2. Uji kuantitatif antioksidan ekstrak daun Papasan

Larutan ekstrak dengan berbagai variasi konsentrasi dipipet sebanyak $2 \mathrm{~mL}$ dimasukkan ke dalam tabung reaksi dan ditambahkan larutan DPPH 40 ppm sebanyak $2 \mathrm{~mL}$. Kemudian dihomogenkan dan diinkubasi dalam ruang gelap selama 30 menit. Kemudian diukur serapannya (Farah et al., 2019).

\section{Uji kuantitatif flavonoid ekstrak daun Papasan}

1. Penetapan panjang gelombang maksimum kuersetin

Sebanyak $1 \mathrm{~mL}$ larutan kuersetin 100 ppm direaksikan dengan $1 \mathrm{~mL} \mathrm{AlCl}{ }_{3} 2 \%$ dan ditambahkan $8 \mathrm{~mL}$ asam asetat $5 \%$ ke dalam tabung reaksi dan dilakukan pembacaan pada rentang panjang gelombang 200-450 nm (Ipandi et al., 2016).

2. Penetapan operating time kuersetin

$1 \mathrm{~mL}$ larutan kuersetin 100 ppm direaksikan dengan $\mathrm{AlCl}_{3} 2 \%$ sebanyak 1 $\mathrm{mL}$ dan asam asetat $5 \%$ sebanyak $8 \mathrm{~mL}$. Absorbansi diukur dengan spektrofotometer UV-Vis pada panjang gelombang maksimum yang telah diperoleh dengan interval waktu 2 menit sampai diperoleh absorbansi yang stabil (Ipandi et al., 2016).

3. Penentuan kurva kalibrasi

Larutan kuersetin dibuat dengan variasi konsentrasi 20; 40; 60; 80; dan 100 ppm lalu didiamkan selama waktu operating time kemudian dibaca absorbansinya pada panjang gelombang maksimum (Tulandi et al., 2015).

4. Pengukuran kandungan flavanoid total ekstrak daun Papasan

$10 \mathrm{mg}$ ekstrak dilarutkan dalam $100 \mathrm{~mL}$ pelarut sehingga diperoleh konsentrasi 100 ppm. Lalu pipet $1 \mathrm{~mL}$ larutan kemudian ditambahkan $1 \mathrm{~mL}$ larutan $\mathrm{AlCl}_{3} 2 \%$ dan 8 $\mathrm{mL}$ asam asetat $5 \%$. Sampel didiamkan selama waktu operating time. Absorbansi diukur dengan spektrofotometer UV-Vis pada panjang gelombang maksimum yang diperoleh. Untuk setiap analisis sampel dibuat dalam tiga replikasi dan diperoleh nilai rata-rata absorbansi.

\section{Analisis data}

Persentase inhibisi didapat dari nilai serapan larutan DPPH sebelum dan sesudah penambahan ekstrak untuk memperoleh persamaan regresi dengan menghitung nilai $\mathrm{IC}_{50}$ dengan rumus :

$$
\% \text { Inhibisi }=\frac{A \text { kontrol-A sampel }}{A \text { kontrol }} \times 100
$$

Keterangan:

A kontrol = Absorbansi tanpa sampel

A sampel $=$ Absorbansi sampel

\section{HASIL DAN PEMBAHASAN}

Determinasi tumbuhan diperlukan diawal sebelum melakukan ekstraksi terhadap daun Papasan untuk memperoleh informasi mengenai identitas tanaman dan menghindari kesalahan dalam penggunaan bagian dari tanaman uji yang digunakan. Hasil determinasi melalui kajian pustaka menunjukkan jenis tanaman uji yang digunakan adalah Coccinia grandis L.

Pada pembuatan simplisia dilakukan proses pencucian, perajangan, pengeringan dan penghalusan bahan. Hal ini dilakukan untuk menghilangkan kotoran berupa benda asing, mengurangi kandungan air yang dapat mempengaruhi hasil ekstraksi dan 
mempermudah terjadinya kontak dengan sampel dan berdifusi lebih banyak ke dalam partikel sampel sehingga proses penyerapan menjadi lebih maksimal karena ukuran partikel yang semakin kecil akan memperluas daya pelarutan sehingga pelarutan komponen dapat lebih merata (Wahyuningsih, 2015).

Simplisia daun papasan diekstraksi dalam pelarut etanol dan metanol dengan metode maserasi yang merupakan metode penyarian tanpa pemanasan dengan merendam serbuk simplisia dalam suatu pelarut organik yang sesuai pada suhu ruangan (Marjoni, 2016). Metode ekstraksi ini memiliki berbagai kelebihan diantaranya adalah pengoperasian yang sederhana, relatif murah dan dapat digunakan pada sampel yang bersifat termolabil. Sedangkan ekstrak air daun papasan diekstraksi dengan metode dekokta melalui pemanasan yang bertujuan untuk menarik simplisia nabati dengan air pada suhu $90^{\circ} \mathrm{C}$ selama 30 menit. Pemilihan metode dekokta dikarenakan pelarut air mempunyai beberapa kelemahan yaitu dapat menyebabkan reaksi fermentatif (mengakibatkan perusakan bahan aktif lebih cepat), pembekakan sel, larutannya mudah terkontaminasi dan merupakan media pertumbuhan yang baik bagi mikroorganisme yang dapat merusak ekstrak yang dihasilkan (Kholifah, 2015).

Hasil ekstraksi simplisia daun Papasan yang berupa ekstrak kental dilakukan penentuan nilai rendemen ekstrak. Rendemen merupakan rasio berat ekstrak yang dihasilkan dengan berat serbuk simplisia yang diekstraksi. Nilai rendemen menunjukkan banyaknya kandungan senyawa aktif yang tersari di dalam pelarut. Semakin besar nilai rendemen, maka senyawa aktif yang tersari dalam pelarut semakin banyak (Santoso et al., 2020).

Pada Tabel 1 menunjukkan persentase rendemen tertinggi terdapat pada ekstrak dalam pelarut metanol dan air yaitu 8,20\% sedangkan yang terendah terdapat pada ekstrak etanol sebesar $5,40 \%$. Hal ini menggambarkan perbedaan pelarut dengan tingkat kepolaran yang berbeda mempengaruhi rendemen yang dihasilkan. Tingginya rendemen ekstrak dalam pelarut metanol dan air menunjukkan metanol dan air mampu mengekstrak senyawa-senyawa aktif dalam ekstrak dengan sifat kepolaran yang mirip dengan pelarut metanol dan air. Berdasarkan tingkat kepolaran, air merupakan pelarut paling polar. Hal ini didasarkan pada tetapan dielektrikum. Semakin besar nilai tetapan dielektrikum, maka semakin polar suatu pelarut. Nilai tetapan dielektrikum pada pelarut air, metanol dan etanol masing-masing yaitu 80; 33; dan 24 (Verdiana et al., 2018).

Tabel 1. Rendemen ekstrak daun Papasan

\begin{tabular}{lccc}
\hline \multirow{2}{*}{ Jenis } & \multicolumn{2}{c}{ Bobot (gram) } & \multirow{2}{*}{ Rendemen } \\
\cline { 2 - 3 } Ekstrak & Ekstrak & Simplisia & \\
\hline Metanol & 16,4 & 200 & $8,20 \%$ \\
Etanol & 10,8 & 200 & $5,40 \%$ \\
Air & 16,4 & 200 & $8,20 \%$ \\
\hline
\end{tabular}

Pada hasil skrining fitokimia menunjukkan ekstrak dalam pelarut etanol mengandung senyawa alkaloid, flavonoid, saponin, tanin, dan steroid sedangkan ekstrak dalam pelarut metanol dan air memiliki kandungan senyawa metabolit sekunder yang sama yaitu flavonoid, alkaloid, saponin, tanin, dan triterpenoid (Tabel 2). Pada penelitian sebelumnya, ekstrak daun Papasan dalam pelarut metanol mengandung senyawa metabolit sekunder berupa glikosida, fenol, alkaloid, flavonoid, tanin dan triterpenoid (Aggarwal et al., 2011). Dalam pelarut etanol, 
hasil ekstraksi daun Papasan mengandung senyawa aktif berupa alkaloid, glikosida dan saponin (Hossain et al., 2014). Adanya perbedaan kandungan senyawa aktif yang dihasilkan dari jenis tanaman yang sama dipengaruhi beberapa faktor diantaranya gen, suhu, kelembaban, cahaya, $\mathrm{pH}$, letak geografis dan kandungan unsur hara dalam tanah (Salim et al., 2016). Selain itu, perbedaan pelarut dalam ekstraksi juga mempengaruhi kandungan senyawa metabolit sekunder yang dihasilkan. Pelarut metanol dapat menyari senyawa-senyawa aktif yang bersifat polar seperti flavonoid, tanin, saponin, dan terpenoid (Verdiana et al., 2018). Etanol yang merupakan pelarut organik dapat menarik senyawasenyawa aktif yang kurang polar hingga polar seperti alkaloid, tanin, saponin, steroid, glikosida dan flavonoid (Sa'adah \& Nurhasnawati, 2015). Pada pelarut air dapat melarutkan senyawa alkaloid dan glikosida (Widyawati et al., 2014). Selain itu, air juga dapat menarik senyawa berupa saponin dan fenolik lainnya seperti flavonoid (Ginting et al., 2015).

Pada uji kualitatif aktivitas antioksidan, dengan penambahan DPPH (2,2-Diphenyl-1picrylhydrazyl) terhadap ketiga ekstrak menunjukkan perubahan warna ungu menjadi kuning. Hal ini memperlihatkan ekstrak etanol, metanol, dan air mempunyai aktivitas antioksidan. DPPH merupakan radikal stabil berwarna ungu gelap yang mengandung nitrogen organik. Setelah bereaksi dengan senyawa antioksidan, warna larutan DPPH akan berkurang dan berubah menjadi kuning (Wahyuningsih, 2013). Hasil ini menunjukkan kesesuaian pada hasil penelitian sebelumnya secara kualitatif, bahwa ekstrak daun Coccinia grandis mempunyai aktivitas antioksidan
(Pavithra et al., 2017). Metode reaksi dengan radikal bebas (DPPH) memiliki beberapa kelebihan diantaranya merupakan metode sederhana, mudah dilakukan, cepat dan sensitif, memerlukan sedikit sampel dalam pengujian dan stabil dalam kondisi penyimpanan yang baik meskipun dalam waktu yang lama (Deshpande et al., 2011).

Tabel 2. Skrining fitokimia ekstrak daun Papasan

\begin{tabular}{lccc}
\hline \multirow{2}{*}{ Senyawa } & \multicolumn{3}{c}{ Ekstrak } \\
\cline { 2 - 4 } & Etanol & metanol & air \\
\hline Flavonoid & + & + & + \\
Alkaloid & + & + & + \\
Saponin & + & + & + \\
Tanin & + & + & + \\
Steroid & + & - & - \\
Triterpenoid & - & + & + \\
\hline
\end{tabular}

Keterangan:

+ : terdapat metabolit sekunder

-: tidak terdapat metabolit sekunder

Uji kuantitatif aktivitas antioksidan dari larutan standar kuersetin dan ketiga ekstrak daun Papasan diukur serapan pada panjang gelombang maksimun $515 \mathrm{~nm}$. Penggunaan kuersetin sebagai larutan standar dalam menentukan aktivitas antioksidan karena merupakan senyawa flavonoid yang memiliki aktivitas biologis seperti antivirus, antibakteri, antiinflamasi, antikanker dan antioksidan yang sangat kuat (Widyasari et al., 2019).

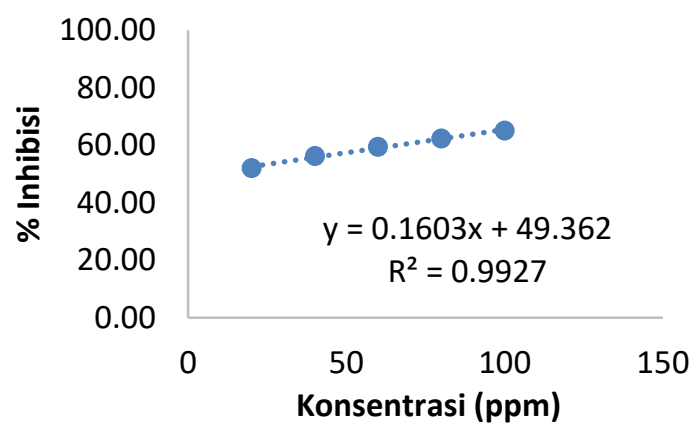

Gambar 1. Kurva baku larutan kuersetin pada penentuan aktivitas antioksidan 
Hasil pengujian aktivitas antioksidan kuersetin yang diperoleh dari persentase inhibisi terhadap konsentrasi memberikan kurva baku dengan persamaan regresi yaitu y $=0,1603 x+49,362$ (Gambar 1). Untuk Ekstrak etanol menunjukkan persamaan regresi yaitu y $=0,1522 x+6,1771$, ekstrak metanol menunjukkan persamaan regresi yaitu $y=$
$0,5831 x+7,2625$ dan ekstrak air memberikan persamaan regresi yaitu $y=0,5938 x+26,362$ (Gambar 2). Dari persamaan tersebut diperoleh nilai $\mathrm{IC}_{50}$ (Inhibition Concentration) yaitu konsentrasi bahan uji yang dapat menghambat aktivitas radikal bebas sebesar $50 \%$ (Julizan et al., 2019).

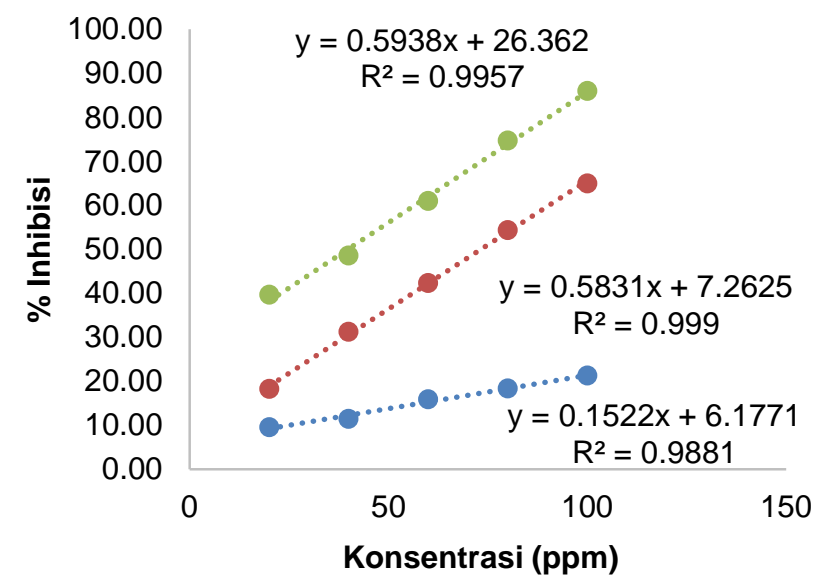

- Ekstrak Etanol

- Ekstrak Metanol

- Ekstrak Air

........ Linear (Ekstrak Etanol)

Linear (Ekstrak Metanol)

- Linear (Ekstrak Air)

Gambar 2. Kurva baku ekstrak metanol, etanol, dan air daun Papasan dalam menentukan aktivitas antioksidan.

Pada larutan uji, nilai $\mathrm{IC}_{50}$ untuk larutan standar kuersetin sebesar 3,98 ppm tergolong antioksidan sangat kuat, ekstrak etanol sebesar 287,92 ppm tergolong antioksidan sangat lemah, ekstrak metanol sebesar 73,29 ppm termasuk antioksidan kuat, dan ekstrak air sebesar 39,8 ppm termasuk antioksidan sangat kuat (Tabel 3). Nilai $I_{50}<50$ ppm tergolong antioksidan sangat kuat, $50-100$ ppm antioksidan kuat, 100-150 ppm antioksidan sedang, 150-200 ppm tergolong antioksidan lemah dan >200 ppm tergolong antioksidan sangat lemah (Rahman et al., 2014). Nilai IC 50 suatu bahan uji berbanding terbalik dengan aktivitas antioksidan. Semakin kecil nilai $\mathrm{IC}_{50}$ maka semakin kuat aktivitas antioksidan.

Pada Tabel 3 dari ketiga esktrak menunjukkan ekstrak daun papasan dalam pelarut air memiliki aktivitas antioksidan terkuat. Hal ini disebabkan banyaknya zat aktif yang tersari ditandai dengan tingginya rendemen yang dihasilkan. Hal ini menunjukkan pelarut air menarik senyawasenyawa aktif yang sebagian besar bersifat sangat polar sebagai antioksidan pada ekstrak. Ekstrak etanol memiliki aktivitas antioksidan yang sangat lemah disebabkan oleh sedikitnya zat aktif yang tersari dan terkandung di dalamnya yaitu dapat dilihat dari persentase rendemen yang paling rendah (Tabel 1). Nilai rendemen yang tinggi memperlihatkan banyaknya komponen senyawa aktif yang tersari di dalam suatu pelarut (Farah et al., 2019).

Aktivitas antioksidan suatu senyawa merupakan senyawa fenolik yang memiliki gugus hidroksil. Senyawa metabolit sekunder sebagai antioksidan diantaranya adalah flavonoid, 
alkaloid, saponin, dan tanin (Lisi et al., 2017; Dalimunthe et al., 2018; Nafiu \& Ashafa, 2017). Senyawa-senyawa tersebut mendonorkan elektron bebas pada atom oksigen di dalam gugus hidroksil atau atom hidrogen yang dapat mereduksi reaktivitas senyawa radikal bebas menjadi stabil (Lantah et al., 2017).

Tabel 3. Nilai $I_{50}$ kuersetin dan ekstrak daun Papasan

\begin{tabular}{lcc}
\hline \multicolumn{1}{c}{ Sampel } & \multicolumn{1}{c}{$\mathrm{IC}_{50}$} & Keterangan \\
\hline Kuersetin & $3,98 \mathrm{ppm}$ & Sangat kuat \\
Ekstrak etanol & $287,92 \mathrm{ppm}$ & Sangat lemah \\
Ekstrak metanol & $73,29 \mathrm{ppm}$ & Kuat \\
Ekstrak air & $39,80 \mathrm{ppm}$ & Sangat kuat \\
\hline
\end{tabular}

Penentuan kandungan flavonoid dari larutan standar kuersetin dan ekstrak daun Papasan dilakukan pengukuran serapan dengan menggunakan spektrofotometer UVVis. Dari hasil pengukuran serapan larutan kuersetin diperoleh kurva baku dengan persamaan regresi yaitu $y=0,0183 x+0,3278$ dengan nilai $\mathrm{R}^{2}$ sebesar 0,9963 (Gambar 3).

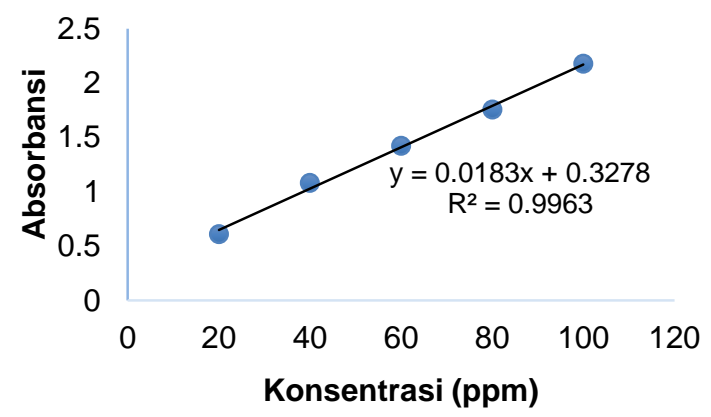

Gambar 3. Kurva baku kuersetin pada penentuan kadar flavonoid

Berdasarkan persamaan regresi yang diperoleh dari larutan baku kuersetin tersebut memberikan kandungan flavonoid total ekstrak daun papasan dalam pelarut etanol adalah 49,825 mg QE/g sedangkan ekstrak metanol dan estrak air memiliki kandungan flavonoid total yang sama dan tertinggi yaitu 50,415 mg QE/g (Tabel 4). Penggunaan kuersetin sebagai larutan standar dalam menentukan kadar flavonoid karena merupakan salah satu turunan senyawa flavonoid dari golongan flavonol yang memiliki 2 gugus fungsi yaitu pada posisi atom C-4 berupa gugus karbonil (-CO-) dan gugus hidroksil (-OH) yang berada pada posisi atom C-3 atau C-5 yang bertetangga dari flavon dan flavonol (Lindawati \& Ma'ruf, 2020).

Ekstrak daun papasan dalam pelarut metanol dan air memiliki kandungan flavonoid yang sama dan tertinggi sedangkan dalam pelarut etanol memiliki kandungan flavonoid terendah. Hal ini menunjukkan senyawa flavonoid pada ekstrak daun papasan memiliki sifat kepolaran yang sama dengan metanol dan air. Flavonoid merupakan senyawa fenolik yang bersifat polar yang dapat larut dalam pelarut polar juga seperti metanol, air dan etanol (Gazali et al., 2019). Kandungan flavonoid ekstrak dalam pelarut etanol paling rendah karena etanol merupakan pelarut organik yang dapat melarutkan senyawa dengan berbagai tingkat kepolaran yaitu nonpolar, semipolar dan polar sehingga tidak semua senyawa aktif yang tersari dalam pelarut etanol mengandung senyawa flavonoid dan turunannya. Hal ini disebabkan etanol memiliki gugus hidroksil yang dapat membentuk ikatan hydrogen sehingga dapat menarik senyawa bersifat polar dan gugus karbon berupa etil $\left(\mathrm{CH}_{3}-\mathrm{CH}_{2}-\right)$ yang dapat menarik senyawa aktif yang bersifat semipolar dan nonpolar.

Flavonoid yang pada umumnya ditemukan di bagian akar, buah, batang, kulit luar batang dan daun tumbuhan memiliki berbagai bioaktivitas dan manfaat bagi kesehatan seperti antibakteri, antivirus, antiradang, antialergi, antikanker, antioksidan, antiinflamasi, pelindung struktur sel, mencegah osteoporosis, dan sebagai antibiotik (Ahmad et al., 2015). 
Tabel 4. Kadar flavonoid total ekstrak daun Papasan

\begin{tabular}{ccccc}
\hline Sampel & $\begin{array}{c}\text { Abseorbansi } \\
\text { Sampel }\end{array}$ & $\begin{array}{c}\text { Konsentrasi } \\
(\mathrm{ppm})\end{array}$ & $\begin{array}{c}\text { Kandungan } \\
\text { Flavonoid Total } \\
(\mathrm{mg} \mathrm{QE} / \mathrm{g})\end{array}$ & $\begin{array}{c}\text { Rata-rata } \\
\text { Kandungan } \\
\text { Flavonoid }\end{array}$ \\
\hline Ekstrak & 2,1281 & 98,37 & 49,185 & \\
Etanol & 2,1730 & 100,83 & 50,415 & $49,825 \mathrm{mg} \mathrm{QE} / \mathrm{g}$ \\
& 2,1730 & 100,83 & 50,415 & \\
Ekstrak & 2,1730 & 100,83 & 50,415 & \\
Metanol & 2,1730 & 100,83 & 50,415 & $50,415 \mathrm{mg}$ QE/g \\
& 2,1730 & 100,83 & 50,415 & \\
Ekstrak & 2,1730 & 100,83 & 50,415 & \\
Aquades & 2,1730 & 100,83 & 50,415 & $50,415 \mathrm{mg}$ QE/g \\
& 2,1730 & 100,83 & 50,415 & \\
\hline
\end{tabular}

Untuk mengetahui adanya perbedaan antara kandungan flavonoid terhadap perbedaan pelarut polar dilakukan uji statistika melalui analisis Kruskall Wallis. Hasil analisis menunjukkan nilai $P$ yang diperoleh lebih besar dari $\mathrm{P}$ Value $(0,05)$. Hal ini menunjukkan Ho diterima atau tidak adanya perbedaan yang signifikan antara kandungan flavonoid ekstrak terhadap perbedaan jenis pelarut polar.

\section{KESIMPULAN}

Berdasarkan hasil penelitian dapat disimpulkan bahwa ekstrak daun Papasan (Coccinia grandis L.) dalam pelarut air memiliki aktivitas antioksidan sangat kuat dengan nilai $\mathrm{IC}_{50}$ sebesar $39,80 \mathrm{ppm}$. Kadar Flavonoid tertinggi ekstrak daun papasan terdapat pada pelarut air sama dengan pelarut metanol sebesar 50,415 mg QE/g. Diperlukan isolasi senyawa aktif golongan flavonoid pada ekstrak daun Papasan (Coccinia grandis L.) yang berperan sebagai antioksidan.

\section{DAFTAR PUSTAKA}

Aggarwal Ashish, S., Suralkar Ujwala, R., Chaudhari Sugandha, G., Deshpande, S. V., Garud Aniket, A., \& Talele Sandeep, G. (2011). Analgesic and antipyretic activity of methanolic extract of Coccinia grandis L. Leaves in experimental animals. Research Journal of Pharmaceutical, Biological and Chemical Sciences, 2(4), 175-182.

Ahmad, A. R., Juwita, J., Ratulangi, S. A. D., \& Malik, A. (2015). Penetapan Kadar Fenolik dan Flavonoid Total Ekstrak Metanol Buah dan Daun Patikala (Etlingera elatior (Jack) R.M.SM). Pharmaceutical Sciences and Research, 2(1), 1-10. https://doi.org/10.7454/psr.v2i1.3481

Arifianti, L., Oktarina, R. D., \& Kusumawati, I. (2014). Pengaruh Jenis Pelarut Pengektraksi. E-Journal Planta Husada, 2(1), 3-6.

Arukwe, U., Amadi, B. A., Duru, M. K. C., Agomuo, E. N., Adindu, E. A., Odika, P. C., Lele, K. C., Egejuru, L., \& Anudike, J. (2012). Chemical composition of Persea americana leaf, fruit and seed. ljrras, 11(2), 346-349.

Ate, O. T., Wisnu, I. M., Putra, A., Ayu, I. G., Kusumawati, W., \& Wayan, N. (2019). Analisis Kadar Total Flavonoid dan Fenolik dari Ekstrak Air Kombinasi Daun Papasan ( Coccinia grandis L ) dan Buah Belimbing Wuluh ( Averrhoa blimbi L ). Jurnal Media Sains 3 (2): 57- 62 P-Issn: 2549-7413 E-Issn: 2620-3847, Vol No 3, 57-62.

Atikawati, Kusumawati, I. G. A. W., Putra, I. M. W. A., \& Yogeswara, I. B. A. (2019). Aktivitas Antioksidan dan Penghambatan Enzim a -amilase Ekstrak Air Kombinasi Daun Papasan ( 
Coccinia grandis [ $L$.]) dan Daun Sembung ( Blumea balsamifera [ L .] DC ). Journal Media Sains, 3(2), 49-56.

Dalimunthe, A., Hasibuan, P. A. Z., Silalahi, J., Sinaga, S. F., \& Satria, D. (2018). Antioxidant activity of alkaloid compounds from litsea cubeba lour. Oriental Journal of Chemistry, 34(2), 1149-1152.

https://doi.org/10.13005/ojc/340270

Deshpande, S. V., Patil, M. J., Parmar, K. K., Daswadkar, S. C., \& Khodade R.B. (2011). A study on antioxidant activity of fruit extracts of Coccinia grandis L. Voigt. International Journal of Drug Research and Technology, 1(1), 69-72. http://ijdrt.com/index.php/drug-researchand-technology/article/view/107/a-studyon-antioxidant-activity-of-fruit-extractsof-coccinia-grandis-I.voigt

Farah, J., Yuliar, \& Marpaung, M. P. (2019). Ekstrak etil asetat daun jambu biji merah (Psidium guajava L.) sebagai antioksidan secara in vitro. JFL : Jurnal Farmasi Lampung, 8(2), 78-86. https://doi.org/10.37090/jl.v8i2.143

Gazali, M., Nafus, H., Nurjnah, \& Zuriat. (2019). Eksplorasi senyawa bioaktif ekstrak daun Nipah ( Nypa fruticans Wurmb ) asal pesisir Aceh Barat sebagai antioksidan ( Nypa Fruticans Wurmb ). Jphpi, 22(1), 155-163.

Ginting, A. F., Suryanto, E., \& Momuat, L. I. (2015). Aktivitas antioksidan ekstrak air dan etanol dari empelur batang Sagu Baruk (Arenga microcarpha). Chemistry Progress, 8(2), 48-54. https://doi.org/10.35799/cp.8.2.2015.13 265

Hossain, S. A., Uddin, S. N., Salim, M. A., \& Haque, R. (2014). Phytochemical and Pharmacological Screening of Coccinia grandis Linn. Journal of Scientific and Innovative Research, 3(1), 65-71. http://www.jsirjournal.com/Vol3_Issue1_ 011.pdf

Ipandi, I., Triyasmono, L., \& Prayitno, B. (2016). Penentuan Kadar Flavonoid Total dan Aktivitas Antioksidan Ekstrak Etanol Daun Kajajahi ( Leucosyke capitellata Wedd .). Pharmascience, 3(1), 93-100.

Julizan, N., Maemunah, S., Dwiyanti, D., \& Anshori, J. Al. (2019). Validasi Penentuan Aktifitas Antioksidan Dengan Metode Dpph. Kandaga- Media Publikasi Ilmiah Jabatan Fungsional
Tenaga Kependidikan, 1(1), 41-45. https://doi.org/10.24198/kandaga.v111.2 1473

Kondhare, D., \& Lade, H. (2017). Phytochemical profile, aldose reductase inhibitory, and antioxidant activities of Indian traditional medicinal Coccinia grandis (L.) fruit extract. 3 Biotech, 7(6), 1-10. https://doi.org/10.1007/s13205017-1013-1

Lantah, P. L., Montolalu, L. A., \& Reo, A. R. (2017). Kandungan fitokimia dan aktivitas antioksidan ekstrak metanol rumput laut Kappaphycus alvarezii. Media Teknologi Hasil Perikanan, 5(3), 167-172.

https://doi.org/10.35800/mthp.5.3.2017. 16785

Lindawati, N. Y., \& Ma'ruf, S. H. (2020). Penetapan kadar total flavonoid ekstrak etanol kacang merah (Phaseolus vulgaris L.) secara spektrofotometri visibel. Jurnal Ilmiah Manuntung, 6(1), 83-91. https://doi.org/10.51352/jim.v6i1.312

Lisi, A. K. F., Runtuwene, M. R. J., \& Wewengkang, D. S. (2017). Aktivitas ekstrak metanol dari daun Soyogik (Saurauia Bracteosa DC.). PHARMACON Jurnal IImiah FarmasiUNSRAT, 6(1), 53-61. https://doi.org/10.35799/jis.17.1.2017.15 614

Marjoni, M. R. (2016). Dasar-dasar fitokimia untuk diploma III farmasi. Trans Info Media.

Nafiu, M. O., \& Ashafa, A. O. T. (2017). Antioxidant and inhibitory effects of saponin extracts from Dianthus basuticus Burt Davy on key enzymes implicated intype 2 diabetes in vitro. Pharmacognosy Magazine, 13(52), S76582. https://doi.org/10.4103/pm.pm_583_16

Nurjanah, Izzati, L., \& Abdullah, A. (2011) Aktivitas Antioksidan dan Komponen Bioaktif Kerang Pisau (Solen spp). IImu Kelautan, 16(3), 119-124. https://doi.org/10.14710/ik.jjms.16.3.119 $-124$

Pavithra, M. K. S., Vijayakumar, L., Anjana, M., Archana, R., Abharna, M., Gayatri, A., Priyadharshini, G., Sivaranjani, E., \& Sumitha, C. (2017). Phytochemical and antioxidant potential of fruit and leaf extracts of Coccinia grandis. 
International Journal of Current Advanced Research, 6(5), 3802-3805. https://doi.org/http://dx.doi.org/10.24327 /ijcar.2017.3805.0371

Pekamwar, S. S., Kalyankar, T. M., \& Kokate, S. S. (2013). Pharmacological activities of Coccinia grandis: Review. Journal of Applied Pharmaceutical Science, 3(5), 114-119. https://doi.org/10.7324/JAPS.2013.3522

Pietta, G. (2000). Flavonoids as Antioxidants. Journal of Natural Products, 63(7) 1035-1042.

Purwandari, R., Subagiyo, S., \& Wibowo, T. (2018). Uji Aktivitas Antioksidan Ekstrak Daun Jambu Biji. Walisongo Journal of Chemistry, 1(2), 66-71. https://doi.org/10.21580/wjc.v2i2.3104

Rahman, N., Bahriul, P., \& Diah, A. (2014). Uji Aktivitas Antioksidan Ekstrak Daun Salam (Syzygium Polyanthum) Dengan Menggunanakan 1,1-Difenil-2Pikrilhidrazil. Jurnal Akademika Kimia, 3(3), 143-149.

Rizkayanti, R., Diah, A. W. M., \& Jura, M. R. (2017). Uji Aktivitas Antioksidan Ekstrak Air dan Ekstrak Etanol Daun Kelor (Moringa Oleifera LAM). Jurnal Akademika Kimia, 6(2), 125. https://doi.org/10.22487/j24775185.201 7.v6.i2.9244

Sa'adah, H., \& Nurhasnawati, H. (2015). Perbandingan pelarut etanol dan air pada pembuatan ekstrak umbi bwang tiwai (Eleutherine americana Merr) menggunakan metode maserasi. Jurnal Ilmiah Manuntung, 1(2), 141-153. https://core.ac.uk/download/pdf/297199 347.pdf

Salim, M., Yahya, Sitorus, H., Ni'mah, T., \& Marini. (2016). Hubungan Kandungan Hara Tanah dengan Produksi Senyawa Metabolit Sekunder pada Tanaman Duku (Lansium domesticum Corr var Duku) dan Potensinya sebagai Larvasida. Jurnal Vektor Penyakit, 10(1), 11-18.

http://ejournal.litbang.kemkes.go.id/inde x.php/vektorp/article/viewFile/6252/4785

Santoso, U., Utari, M., \& Marpaung, M. P. (2020). Aktivitas antibakteri dan antijamur ekstrak batang akar kuning ( Fibraurea chloroleuca Miers ) terhadap Escherichia coli, Staphylococcus aureus dan Candida albicans. 20(2), 194-208.
Simaremare, E. S. (2014). Skrining Fitokimia Ekstrak Etanol Daun Gatal (Laportea decumana (Roxb.) Wedd). Pharmacy, 11(1), 98-107.

Tulandi, G. P., Sudewi, S., \& Lolo, W. A. (2015). Validasi Metode Analisis Untuk Penetapan Kadar Parasetamol Dalam Sediaan Tablet Secara Spektrofotometri Ultraviolet. PHARMACONJurnal IImiah Farmasi-UNSRAT, 4(4).

Verdiana, M., Widarta, I. W. R., \& Permana, I. D. G. M. (2018). Pengaruh Jenis Pelarut Pada Ekstraksi Menggunakan Gelombang Ultrasonik Terhadap Aktivitas Antioksidan Ekstrak Kulit Buah Lemon (Citrus limon (Linn.) Burm F.). Jurnal Ilmu Dan Teknologi Pangan (ITEPA), $\quad 7(4), \quad 213$. https://doi.org/10.24843/itepa.2018.v07.i 04.p08

Wahyuningsih, T. (2013). Perbandingan Aktivitas Antioksidan Minyak Atsiri dan Ekstrak Etanol Daun Gelam Tikus (Melaleuca leucadendra var. minor (Sm.) Duthie) Menggunakan Metode DPPH. Journal of Chemical Information and Modeling, 53(9), 1689-1699. https://doi.org/10.1017/CBO978110741 5324.004

Wahyuningsih, T. (2015). Perbandingan Aktivitas Antioksidan Minyak Atsiri dan Ekstrak Etanol Daun Gelam Tikus (Melaleuca leucadendra var. minor (Sm.) Duthie) Menggunakan Metode DPPH.

Widyasari, E. M., Sriyani, M. E., Daruwati, I., Halimah, I., \& Nuraeni, W. (2019). Karakteristik fisiko-kimia senyawa bertanda 99mTc-Kuersetin. Jurnal Sains Dan Teknologi Nuklir Indonesia, 20(1), 9-18.

https://doi.org/https://doi.org/10.17146/js tni.2019.1.1.4108

Widyawati, P. S., Budianta, T. D. W., Kusuma, F. A., \& Wijaya, E. L. (2014). Difference of solvent polarity to phytochemical content and antioxidant activity of Pluchea indicia less leaves extracts. International Journal of Pharmacognosy and Phytochemical Research, 6(4), 850855.

Zirconia, A., Kurniasih, N., \& Amalia, V. (2015). Identifikasi Senyawa Flavonoid Dari Daun Kembang Bulan (Tithonia Diversifolia) Dengan Metode Pereaksi Geser. Al-Kimiya, 2(1), 10-11. 